DOI

\title{
МЕХАНІЗМИ ЗАПАЛЬНИХ ТА АВТОІМУННИХ РЕАКЦІЙ ПРИ ЧЕРЕПНО-МОЗКОВІЙ TPABMI
}

\author{
○С. В. Зябліцев, я. С. Юзьків \\ Національний медичний університет імені О. О. Богомольця, Київ
}

РЕЗЮМЕ. У модельному експерименті на білих щурах-самцях із черепно-мозковою травмою середньотяжкого ступеня було показано, що механізми запальних та автоімунних реакцій включають прогресувальне наростання циркулюючих імунних комплексів та С-реактивного білка; значне накопичення у крові нейроспецифічних білків S100B, NSE і GAPF, а починаючи з 7 доби, - автоімунних антифосфоліпідних антитіл, що могло бути пов'язано із різким приростом рівня прозапальних цитокінів, особливо інтерлейкіну $1 \beta$ та інтерлейкіну 6.

КЛЮчОВІ СлОВА: черепно-мозкова травма, автоімунні механізми, S100B, прозапальні інтерлейкіни.

Вступ. Сучасні дані щодо спрямованості імунологічних реакцій при черепно-мозковій травмі (ЧМТ) досить суперечливі [1, 2]. На жаль, до кінця не ясно - чому саногенетичні по своїй суті реакції імунної системи (зв'язування надлишку антигенів, які надходять у кров після травми) у певної частини хворих в подальшому трансформуються в патологічні (автоімунні реакції пошкодження нервової тканини) [3, 4]. Отже, не виключено, що розвиток автоімунних реакцій запускає окремі механізми пошкодження компонентів гематоенцефалічного бар'єру, нейронів та гліоцитів, що, у свою чергу, може поглиблювати ступінь гіпоксійних та метаболічних порушень, активувати процеси нейродегенерації.

Як було показано [5], у патогенезі ЧМТ важлива роль належить запально-токсичним процесам, які складають основу вторинного пошкодження тканини мозку. Запально-токсична стадія розвивається вже з другої доби при середньотяжкій ЧМТ, змінюючи передуючу їй реактивно-метаболічну стадію, та після виснаження компенсаторно-пристосувальних механізмів закінчується розвитком системної ендогенної інтоксикації i поліорганної недостатності. Предикторами розвитку запально-токсичної стадії $\epsilon$ гіперферментемія - різкий приріст активності амінотрансфераз, лужної та кислої фосфатаз, рівня катепсину $\mathrm{D}$, що відображає ушкодження клітинних та лізосомальних мембран, а також збільшення вмісту в крові циркулюючих імунних комплексів (ЦІК), С-реактивного білка (СРБ), активацію інтерлейкінового каскаду із залученням інтерлейкіну (IL) $1 \beta$, фактора некрозу пухлин (TNF- $\alpha$ ), IL-6 та IL-8. У цій стадії спостерігається також приріст рівня у крові маркерів пошкодження нервової тканини - білка S100B, нейроноспецифічної енолази (NSE) та білка цитоскелета астроцитів - гліального фібрилярного кислого білка (GAPF) [6-8]. На наш погляд, це може бути пов'язано із прогресуванням порушення цілісності структур гематоенцефалічного бар'єру та розвитком автоімунних гуморальних реакцій. Відповідно до викладеного, метою дослідження було з'ясування наявності та характеру запальних та автоімунних реакцій при експериментальній ЧМТ.

Матеріал і методи дослідження. Експерименти було проведено на 95 білих безпородних щурах-самцях масою 180-200 г, яким наносили ЧМТ середньотяжкого ступеня за моделлю В. М. Єльського, С. В. Зябліцева (2005) [9]. Згідно з класичною моделлю, вантаж заданої маси вільно падав на фіксовану голову тварини, що завдавало концентрований удар (імпресійна травма). Маса вантажу складала 66,7 г, висота падіння 65 см, площа удару $0,5 \mathrm{~cm}^{2}$, що дозволяло отримувати удар 3 енергією 0,425 Дж. Патологоанатомічне дослідження показало, що у тварин мала місце закрита ЧМТ при наявності шкірної гематоми і перелому кісток склепіння черепа без зсуву з наявністю розтрощення кори тім'яних і скроневих часток (у зоні удару) й основи лобних і скроневих часток (у зоні протиудару), а також ушкодження речовини головного мозку у вигляді дифузних дрібноточкових крововиливів та «оболонкова" гематома (в зоні удару); летальність у гострому періоді склала 45,0 \%. Це дало змогу вважати це ушкодження травмою середньотяжкого ступеня. Строки спостереження склали 1, 3, 7, 14 та 21 добу після травми. У якості контролю використовували хибнотравмованих тварин, яких у кількості 5 виводили з експерименту у відповідні строки. У динаміці посттравматичного періоду у крові імуноферментним методом визначали вміст нейроспецифічних білків S100B, NSE i GAPF; IL-1 $\beta$, IL-6, IL-8, TNF $\alpha$ і CPБ, а також антитіл до кардіоліпіну (АТ-КЛ) і антифосфоліпідних (АФЛ) антитіл - імуноглобуліни (Ig) М та G (набори реактивів DRG International, Inc. та BioVender Corp.). Вміст у крові ЦІК вимірювали спектрометричним методом (набори реактивів "La Chema»). Статистичні розрахунки здійснювали в середовищі прикладних програм Statistica 10 (StatSoft, Inc., USA).

Результати й обговорення. На першому етапі дослідження була вивчена динаміка рівня у 
Огляди літератури, оригінальні дослідження, погляд на проблему крові (табл. 1) нейрональних білків (S100B, NSE та GFAP), які з'являються у крові при ЧМТ внаслідок

процесів нейродеструкції та порушення цілісності гематоенцефалічного бар'єру [8].

Таблиця 1. Динаміка вмісту у крові нейроспецифічних білків S100B, NSE та GFAP (M $\pm m)$

\begin{tabular}{|c|c|c|c|c|c|c|}
\hline \multirow{2}{*}{ Показник } & \multirow{2}{*}{ Контроль } & \multicolumn{5}{|c|}{ Доба } \\
\cline { 3 - 7 } & & 1 & 3 & 7 & 14 & 21 \\
\hline S100B, пкг/Мл & $20,3 \pm 1,8$ & $145,7 \pm 12,0 *$ & $155,6 \pm 12,3 *$ & $201,7 \pm 14,1$ * & $224,2 \pm 21,5$ * & $203,0 \pm 18,3$ * \\
\hline NSE, нг/мл & $2,06 \pm 0,14$ & $9,51 \pm 0,80 *$ & $23,71 \pm 2,44 *$ & $28,66 \pm 3,06 *$ & $33,08 \pm 3,53$ * & $24,16 \pm 2,21$ * \\
\hline GFAP, пкг/Мл & $25,4 \pm 1,6$ & $84,2 \pm 7,6 *$ & $30,8 \pm 2,7$ & $47,3 \pm 4,8 *$ & $42,8 \pm 3,2$ * & $31,6 \pm 2,9$ \\
\hline
\end{tabular}

Примітка.* - p < 0,05 при порівнянні середніх величин з контрольною групою.

Через 1 і 3 доби після травми рівень білка S100B перевищував контрольні значення В $7,2-7,7$ раза $(p<0,05)$. Вторинний приріст його рівня в крові відбувся через 7 діб після травми - В 9,9 раза; надалі його рівень стабілізувався на цих значеннях, перевищуючи контрольний через 14 і 21 добу після травми у 10-11 разів. При цьому зростання на 7 добу у зіставленні з показником 3 доби було статистично значущим (у 1,3 раза, $\mathrm{p}<0,05)$. Отже, зростання рівня в крові білка S100B відбувалося не поступово, а стрибкоподібно із двома піками: перший - вже через 1 , а другий через 7 діб після травми. Вочевидь, у пізньому періоді відбувалося посилення деструкції нервової тканини за рахунок розвитку вторинної гіпоксії, енергодефіциту і нейродегенерації.

NSE вважають маркером залучення нервової тканини до патологічного процесу, а кількісне ії визначення в спинномозковій рідині або в сироватці крові - прогностичним критерієм ступеня вираженості ушкоджень нейронів, а також порушення проникності гематоенцефалічного бар'єра; приріст NSE у крові та спинномозковій рідині характеризує ступінь гіпоксійного й постішемічного ушкодження мозку [7].

У посттравматичному періоді рівень NSE (див. табл. 1) істотно підвищувався й в усі терміни спостереження був статистично значуще вищим від контрольних величин. При цьому характер зростання рівня NSE, на відміну від білка S100B, був не стрибкоподібним, а поступальним, однак відрізнявся значно більшою вираженістю. Так, через 7 діб після травми рівень NSE перевищив контрольний у 14 разів. Цей факт, як і у випадку з білком S100B, указував на погіршення стану мозкової тканини на 7 добу після травми. Через 14 і 21 добу після травми рівень NSE перевищував контрольний у 12-16 разів. Це вказувало на прогресування деструкції нервової тканини й порушення функції гематоенцефалічного бар'єру у пізній термін після травми.

Строго специфічним маркером деструкції нервової тканини вважають GFAP, який $\epsilon$ основним білком цитоскелета астроцитів [6]. Його рівень досить специфічно підвищується в гострій фазі посттравматичної реакції та відповідає тяжкості травматичного ушкодження $[7,8]$. У наших дослідженнях відмічено різке зростання вмісту GFAP у крові (див. табл. 1) вже на 1 добу у 3,3 раза з подальшим зниженням майже до норми на 3 добу. Але на 7 добу було відмічено повторне збільшення рівня GFAP, яке зберігалося і на 14 добу. На 21 добу рівень білка повторно повертався до норми. Отже, динаміка рівня у крові GFAP відрізнялася двома піками - через 1 добу і, повторно, - на 7-14 добу посттравматичного періоду.

У посттравматичному періоді було відмічено накопичення автоімунних антитіл (рис. 1).

Більшою мірою це стосувалося АТ-КЛ, різкий приріст їх вмісту відбувався вже з 1 доби, а з 3 рівень АТ-КЛ стрибкоподібно зростав та перевищував контрольні значення майже у 25 разів на 14 добу після травми.

Також позитивна, але повільніша динаміка була притаманна накопиченню у крові антитіл до фосфоліпідів, яке починалося з 3 доби та сягало 5-кратного приросту на 21 добу. Отже, після ЧМТ у крові були наявні певні ознаки розвитку автоімунного процесу, які характеризувалися одразу після травми накопиченням маркерів пошкодження нервової тканини, а згодом - відповідною реакцією активації утворення автоімунних антифосфоліпідних антитіл.

Для моніторингу запальних процесів у крові була визначена динаміка ЦІК і СРБ. Протягом 1 доби після травми рівень ЦІК різко підвищувався (у 3-3,5 раза), через 7 діб - у 4-5 разів, після чого залишався на тому ж стабільно високому рівні. Рівень СРБ стрімко підвищувався і через добу після травми перевищував початковий рівень у 11-12 разів, а у подальшому - у 20-25 разів. Нагромадження в крові ЦІК, як відомо [2], викликає розвиток повсюдного запалення в судинах мікроциркуляторного русла, що становить одну з важливих шокогенних реакцій. В умовах ЧМТ різке наростан- 
Огляди літератури, оригінальні дослідження, погляд на проблему

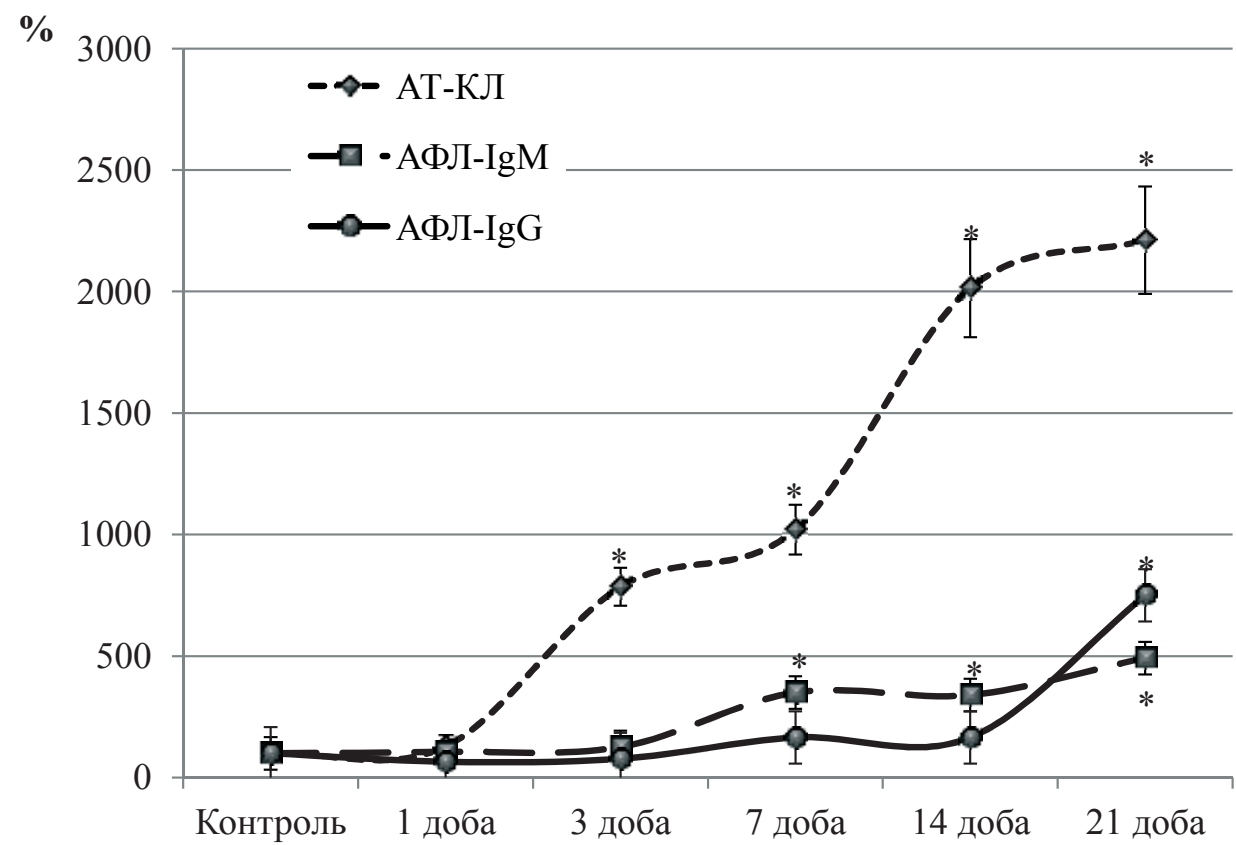

Рис. 1. Динаміка вмісту автоімунних антитіл (АТ-КЛ, АФЛ-IgM і АФЛ-ІgG) при ЧМТ (всі показники виражені у \% від контрольного рівня, що прийнятий за 100 \%); * - p < 0,05 при порівнянні середніх величин з контрольною групою.

ня ЦІК могло бути розцінене як захисно-компенсаторна реакція, спрямована на зв'язування надлишку мозкових автоантигенів. Наступне надмірне нагромадження ЦІК, на нашу думку, було реакцією ушкодження, яка спричиняла генералізацію запальної реакції, що підтверджувалося багаторазовим збільшенням рівня у крові СРБ.
При ЧМТ у головному мозку IL-1及 синтезується, як і інші прозапальні цитокіни, гліальними та ендотеліальними клітинами в зоні ураження й перифокальній зоні $[10,11]$. Вміст IL-1 $\beta$ у крові (рис. 2) стрімко наростав, особливо - на 7 добу (у 15 разів порівняно з контролем), але ж значного проросту він сягав вже і на 1 добу.

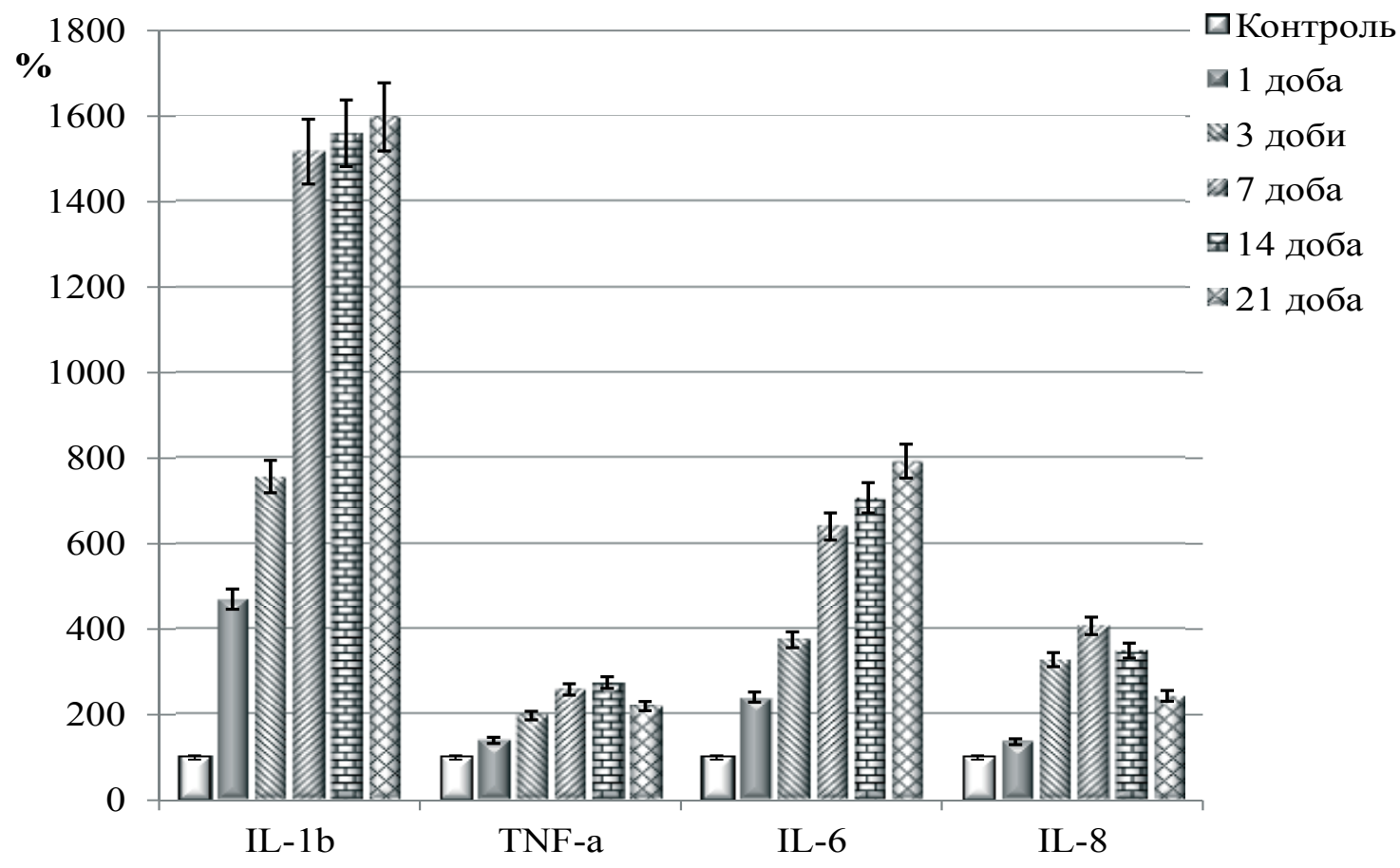

Рис. 2. Динаміка вмісту інтерелейкінів (всі показники виражені у \% від рівня контрольної групи, що прийнятий за $100 \%) ; ~ *-p<0,05$ при порівнянні середніх величин з контрольною групою. 
Огляди літератури, оригінальні дослідження, погляд на проблему

Це вказувало на активацію запальної реакції вже у гострому періоді, а подальше зростання IL-1 $\beta$ відображало генералізацію запальної реакції. Вміст у крові IL-6 та IL-8 також прогресивно збільшувався, але, у порівнянні з IL-1 $\beta$, відстрочено максимумом на 7-21 добу. Основними функціями IL-6 $\epsilon$ запуск антитілоутворення B-лімфоцитами, а IL-8 - активація хемотаксису у осередок запалення Т-лімфоцитів та макрофагів [4]. Таким чином, залучення цитокінів "другого каскаду» могло запускати розвиток реакції автоімунного пошкодження нервової тканини у пізньому періоді ЧМТ, що особливо стосувалося IL-6, оскільки й інші дослідження показують активацію В-лімфоцитів та процесу антитілоутворення, на противагу Т-клітинній імунодепресії [4].

У плані обговорення отриманих результатів можна повернутися до білка S100B, який при ви-

сокій концентрації має нейротоксичну активність: у мікромолярних концентраціях позаклітинний S100B діє нейротоксично, індукуючи не тільки апоптоз, але й некроз $[12,13]$. Це зумовлено здатністю S100B активувати прозапальні цитокіни, оксидативний стрес, індуцибельну NO-синтазу [14]. Тобто, саме S100B може підсилювати експресію IL-1 $\beta$, i IL-6 у нервовій тканині, а через активацію утворення NO - також і IL-8, і TNFa. У свою чергу, ці інтерлейкіни індукують експресію S100B, утворюючи замкнене коло нейротоксичних ефектів цього білка. Паралельне і прогресуюче зростання вмісту нейрональних білків і прозапальних цитокінів саме й становить підґрунтя замкненого патогенетичного кола, що формувалося, починаючи з 7 доби після травми.

Узагальнююча схема розвитку запальної та автоімунної реакції представлена на рисунку 3.

\begin{tabular}{|c|c|}
\hline \multicolumn{2}{|c|}{ ЧМТ } \\
\hline$\downarrow$ & $\downarrow$ \\
\hline $\begin{array}{c}\text { деструкція нейронів } \\
\text { ( } \uparrow \text { S100B, NSE та GFAP) }\end{array}$ & $\begin{array}{l}\text { порушення цілісності структур } \\
\text { гематоенцефалічного бар'єру }\end{array}$ \\
\hline$\downarrow$ & $\downarrow$ \\
\hline \multicolumn{2}{|c|}{ демаскування нейрогліальних антигенів } \\
\hline$\downarrow$ & $\downarrow$ \\
\hline $\begin{array}{c}\text { активація системного запалення } \\
\text { ( } \uparrow \text { ЦІК, СРБ, Il-1, TNFa) }\end{array}$ & $\begin{array}{c}\text { активація інтерлейкінів «другого } \\
\text { каскаду" } \\
\text { (Il-6 та Il-8) із залученням T- } \\
\text { лімфоцитів та макрофагів }\end{array}$ \\
\hline$\downarrow$ & $\downarrow$ \\
\hline
\end{tabular}

Рис. 3. Схема розвитку запальної та автоімунної реакцій при ЧМТ.

Демаскування нейрональних антигенів внаслідок порушення гематоенцефалічного бар'єру та запуск автоімунної реакції можуть бути ще одним механізмом нейродегенерації у пізньому періоді після ЧМТ.

Висновки. 1. За умов середньотяжкої експериментальної ЧМТ різке наростання ЦІК у перші доби після травми могло бути розцінене як захисно-компенсаторна реакція, спрямована на зв'язування надлишку мозкових автоантигенів, але наступне прогресувальне нагромадження ЦІК було реакцією ушкодження, яка спричиняла генералізацію запальної реакції, що підтверджувалося багаторазовим збільшенням рівня у крові СРБ.

2. Після ЧМТ у крові були наявні певні ознаки розвитку автоімунного процесу, які характеризувалися одразу після травми накопиченням маркерів пошкодження нервової тканини (нейроспецифічних білків S100B, NSE і GAPF), а згодом - відповідною реакцією активації утворення автоімунних антифосфоліпідних антитіл (АТ-КЛ, АФЛ-IgM і АФЛ-IgG). Реакцію автоімунного пошкодження нервової тканини у пізньому періоді ЧМТ могло спричиняти залучення цитокінів «другого каскаду» (IL-6 та IL-8).

3. Паралельне і прогресуюче зростання вмісту нейрональних білків, особливо S100B, і прозапальних цитокінів, особливо IL-1 $\beta$ і IL-6, може становити підґрунтя формування замкненого патогенетичного кола, яке активувало запальні та автоімунні реакції та формувалося починаючи 3 7 доби після травми.

Перспективи подальших досліджень. Перспективним розвитком цього напрямку могло 6 бути вивчення на доказовому рівні реакцій та механізмів контакту нейроспецифічних білків, зокрема S100B, з імунокомпетентними клітинами нервової тканини (глія, макрофаги, лімфоцити) при експериментальній ЧМТ методом імуногістохімічного дослідження з використанням моноклональних кон'югованих антитіл. 
Огляди літератури, оригінальні дослідження, погляд на проблему

\section{ЛІТЕРАТУРА}

1. Горбунов В. И. Иммунопатология травматической болезни головного мозга / В. И. Горбунов. - Ульяновск, 1996. - С. 409-421.

2. Иммунный статус в остром периоде тяжелой черепно-мозговой травмы при развитии гнойно-септических осложнений / Т. И. Борщикова, Н.Н.Епифанцева, Г.С. Суржикова [и др.]//Общая реаниматология.-2010.№ 6 (3). - С. 35-42. doi:10.15360/1813-9779-2010-3-35.

3. Мамытова Э. М. Особенности иммунных нарушений в остром периоде черепно-мозговой травмы / Э. М. Мамытова, Э. С. Майназарова, А. Т. Жусупова // Вестник КРСУ. - 2014. - Т. 14, № 4. - С. 120-123.

4. Иммунологические изменения при черепномозговой травме / Р. Х. Исаева, И. А. Антонюк, А. В. Гридякина, А. Е. Евстафьева // Международный журнал прикладных и фундаментальных исследований. 2014. - № 8 - С. 41-47.

5. Коровка С. Я. Механізми формування синдрому ендогенної інтоксикації при травматичній хворобі головного мозку : автореф. дис. на здобуття наук. ступеня канд. мед. наук : спец. 14.03.04 «Патологічна фізіологія» / С. Я. Коровка. - Донецьк, 2013. - 20 с.

6. Acute Temporal Profiles of Serum Levels of UCH-L1 and GFAP and Relationships to Neuronal and Astroglial Pathology following Traumatic Brain Injury in Rats / X. J. Huang, O. Glushakova, S. Mondello [et al.] // J. Neurotrauma. -2015.Vol. 32 (16). - P. 1179-1189. doi:10.1089/neu.2015.3873.

7. Храпов Ю. В. Роль биомаркеров повреждения вещества головного мозга в диагностике, оценке эффективности лечения и прогнозировании исходов тяжелой черепно-мозговой травмы / Ю. В. Храпов, С. В. Порой- ский // Волгоградский научно-медицинский журнал. 2013. - № 3. - С. 10-20.

8. Білошицький В. В. Можливості біохімічних біомаркерів як засобів прогнозування перебігу черепномозкової травми / В.В.Білошицький, О. Я. Кобилецький // Український нейрохірургічний журнал. - 2015. № 1. - С. 4-14.

9. Ельский В. Н. Моделирование черепно-мозговой травмы / В. Н. Ельский, С. В. Зяблицев. - Донецк : Изд-во «Новый мир», 2008. - 140 с.

10. Абу Салех Аммар Ибрахим. Роль цитокинов в патогенезе острого периода черепно-мозговой травмы : автореф. дис. на соискание уч. степени канд. мед. наук : спец. 14.00.13 «Нервные болезни» / Абу Салех Аммар Ибрахим. - Москва, 2007. - 22 с.

11. Neutralization of interleukin-1beta modifies the inflammatory response and improves histological and cognitive outcome following traumatic brain injury in mice // F. Clausen, A. Hảnell, M. Björk [et al.] // Eur. J. Neurosci. 2009. - Vol. 30 (3). - P. 385-396.

12. S100B expression in and effects on microglia / C. Adami, G. Sorci, E. Blasi [et al.] // Glia. - 2001. - Vol. 33. P. 131-142.

13. Роль апоптозу в системних проявах тяжкої травми / А. А. Гудима, М. Р. Хара, Л. С. Фіра [та ін.]. Тернопіль: Укрмедкнига, 2010. - 241 с.

14. Нейронспецифические белки - маркеры энцефалопатии при тяжёлой сочетанной травме / Е. В. Григорьев, Г. В. Вавин, Т. Г. Гришанова [и др.] // Медицина неотложных состояний. - 2010. - № 2 (27). C. 87-92.

\section{INFLAMMATORY AND AUTOIMMUNITY MECHANISMS OF BRAIN INJURIES}

\section{@) S. V. Ziablitsev, Ya. S. Yuzkiv}

\section{O. Bohomolets National Medical University, Kyiv}

SUMMARY. In a model experiment on white rats-males with the middling-heavy degree craniocerebral trauma it was shown that inflammatory and autoimmunity mechanisms include progressive growth of circulatory immune complexes and C-reactive protein; considerable accumulation in blood of neurospecific proteins, such as S100B, NSE and GAPF and, beginning from 7-th day, - autoimmune anti-phospholipid antibodies. It could be related to significant increase of proinflammatory cytokines, especially interleukine-1 $\beta$ and interleukine-6.

KEY WORDS: brain injury, autoimmune mechanisms, S100B, pro-inflammatory cytokines. 